Original Research Paper

\title{
Screening and Characterization of Sponge-Associated Bacteria Producing Bioactive Compounds Anti-Vibrio sp.
}

\author{
Aris Tri Wahyudi, Jepri Agung Priyanto, Wenang Maharsiwi and Rika Indri Astuti \\ Division of Microbiology, Department of Biology, \\ Faculty of Mathematics and Natural Sciences, Bogor Agricultural University, Bogor, Indonesia
}

\author{
Article history \\ Received: 31-07-2018 \\ Revised: 31-08-2018 \\ Accepted: 04-10-2018 \\ Corresponding Author: \\ Aris Tri Wahyudi \\ Division of Microbiology, \\ Department of Biology, Faculty \\ of Mathematics and Natural \\ Sciences, Bogor Agricultural \\ University, Bogor, Indonesia \\ Email: aristri2011@gmail.com
}

\begin{abstract}
In Indonesia, vibriosis is the main disease in shrimp. This disease is caused by Vibrio sp that may decrease the productivity of shrimp cultivation. Thus, exploration for new bioactive compounds as vibriosis biocontrol agent is necessary. Marine sponge-associated bacteria is one of many sources for bioactive compounds. The aim of this study was to screen marine sponge-associated bacteria producing anti-Vibrio sp's bioactive compounds. Total 12 bacterial isolates (15\%) of 80 isolates was isolated from marine sponges Hyrtios sp, Verongula sp. and Smenospongia sp. had anti-Vibrio sp activity in different spectra. The hemolytic assay showed that these 12 bacteria were not pathogen. Interestingly, 3 out of 4 potential isolates with the best anti-Vibrio activity have been confirmed to have genes involved in the synthesis of bioactive compounds, mainly Polyketide Synthase (PKS) and Non-Ribosomal Peptide Synthetase (NRPS) based on the occurrence of Ketosynthase (KS) and Adenilase (A) domain, respectively. Based on 16S rRNA gene, those four isolates were highly homolog to the Bacillus sp in different species and strains. Isolate coded as P2.24 was the only bacterium that had the widest spectrum of anti-Vibrio bioactive compounds against three Vibrio sp used i.e., Vibrio harveyi, V. parahaemolyticus, V. vulnificus. Consistently, an anti- Vibrio sp. activity of the P2.24 was also shown by antagonism assay using culture, supernatant and crude extract of the isolate. Our study indicates this bacterial isolate potentially to be further exploited for controlling vibriosis biologically and important for elucidation of bioactive compounds synthesized by this bacterium.
\end{abstract}

Keywords: Bioactive Compounds, Sponge-Associated Bacteria, PKS, NRPS, Vibriosis, 16S rRNA

\section{Introduction}

Vibrio sp. can cause vibriosis that is a common disease in marine aquaculture around the world. These bacteria can infect shrimp and result in mass death. One of the aquaculture animals that is often infected by Vibrio sp. is shrimp. Commonly, vibriosis affects shrimp in all stadia, including larvae, protozoea and post larvae and causes deaths of $80-85 \%$ of the total population (Chatterjee and Haldar, 2012; Aguirre-Guzman et al., 2013). The application of antibiotics for vibriosis treatment is indeed able to reduce the impact, but its use in the long term still remain negative impacts on the environment, including resistance case and accumulation of antibiotic residues on cultivated products. Therefore, the discovery of new bioactive compounds as vibriosis biocontrol agent that more effective and environmental friendly is necessary.

The sponge has been known as the most potential source of marine natural products (Taylor et al., 2007). Selvin and Lipton (2004) reported that secondary metabolites from marine sponge Dendrilla nigra are able to inhibit Vibrio harveyi and $V$. alginolyticus infecting Paneus monodon. However, the development of sponge's bioactive compounds is hampered due to the limitation of sponge biomass in the environment. The concentration of bioactive compounds in sponge tissue can be very low. Consequently, the large amounts of sponge biomass are needed for large-scale production. For example, to get $18 \mathrm{~g}$ of bryostatin, 
$13.000 \mathrm{~kg}$ of sponge Bryozoans neritina biomass are needed (Taylor et al., 2007).

In addition, the sponge has symbiosis interaction with marine microorganisms, especially bacteria. They are a potential source of bioactive compounds with various biological activities, including antibacterial (Yoghiapiscessa et al., 2016), antifungal (Ozkaya et al., 2014), antiviral (Hassan and Ibrahim, 2016) and other bioactivities. Rini et al. (2017) reported that some bacteria isolated from marine sponge Aaptos sp. and Hyrtios sp. were able to inhibit B. subtilis, Escherichia coli, $V$. parahaemolyticus, $V$. harveyi, $V$. vulnificus. Other marine bacteria associated with sponge Jaspis sp. also exhibited antibacterial properties against Staphylococcus aureus, $V$. harveyi, E. coli, Pseudomonas aeruginosa, EPEC K-11, yeast Candida albicans and C.tropicalis as reported by Abubakar et al. (2011). It is worth noting that some of the spongeassociated bacteria have been detected to have the genes encoding the enzyme that may correlate for bioactive compounds synthesis, including Non-Ribosomal Peptide Synthetase (NRPS) and Polyketide Synthase (PKS) (Brinkmann et al., 2017; Zhang et al., 2009a). Exploration of marine bacteria from Indonesian sea sponge has been rarely reported. Therefore, the aim of this study was to screen marine sponge-associated bacteria producing antiVibrio spp.'s bioactive compounds.

\section{Materials and Methods}

\section{Isolation of Sponge-Associated Bacteria}

Sponges used in this study were Hyrtios sp., Verongula sp., Smenospongia sp. collected from Kepulauan Seribu Jakarta, Indonesia. Serial dilution method was applied in this study. One $\mathrm{g}$ of sponge biomass was washed by sterile seawater, then crushed aseptically. This materials were homogenized and serially diluted in $9 \mathrm{~mL}$ of $0.85 \% \mathrm{NaCl}$ solution from $10^{-1}$ to $10^{-4}$ dilution. Nearly $100 \mu \mathrm{L}$ suspension of each serial dilution was plated into seawater complete (SWC) agar medium (1 $\mathrm{g}$ yeast extract, $3 \mathrm{~mL}$ glycerol, $5 \mathrm{~g}$ peptone, $250 \mathrm{~mL}$ distilled water and $750 \mathrm{~mL}$ seawater, $15 \mathrm{~g}$ agar) by spread plate technique, then incubated for $24-36 \mathrm{~h}$ at $\pm 27^{\circ} \mathrm{C}$.

\section{Screening of Bacteria Producing Bioactive Compounds Anti-Vibrio sp}

Bacterial target used in this study were Vibrio parahaemolyticus ATCC 17802 and Vibrio vulnificus 195B (collection of standard of fish quarantine, quality control and fishery product safety, Jakarta, Indonesia) and Vibrio harveyi P-275 (collection of research and development center of brackish water aquaculture, Maros, Indonesia). Each bacterium was cultured in SWC medium and incubated for $24 \mathrm{~h}$ at $27^{\circ} \mathrm{C}$, then used as a starter. About $500 \mu \mathrm{L}$ or $1 \%(\mathrm{v} / \mathrm{v})$ of that bacterial suspension were inoculated to $50 \mathrm{~mL}$ of melted SWC medium and poured into a sterile plate. After the medium containing the target bacteria was solid, each of 80 bacterial isolates was streaked onto the inoculated medium, then incubated for $24 \mathrm{~h}$ at $\pm 27^{\circ} \mathrm{C}$.

\section{Hemolytic Test}

Twelve bacterial isolates producing anti-Vibrio $\mathrm{sp}$ compounds were tested to know their hemolytic activity. Each of bacterial isolate was streaked onto blood agar medium and incubated for $24 \mathrm{~h}$ at $\pm 27^{\circ} \mathrm{C}$.

\section{Identification of NRPS-PKS Genes of the Potential Bacteria}

Genomic DNA of bacterial cultures was extracted by using Presto ${ }^{\text {TM }}$ Mini gDNA bacteria Kit (Geneaid) according to the protocol's instructions. DNA quality and concentration were determined by using a Nanodrop ${ }^{\mathrm{TM}} 1000$ Spectrophotometer. Adenylation (A) domain of NRPS gene and Ketosynthase (KS) domain of PKS gene from bacterial isolate were amplified by PCR using primer MTF/R (f: 5' AAR DSI GGI GSI GSI TAY BIC C-3); (r: 5-97 CKR WAI CCI CKI AIY TTI AYY TG-3) which targeted \pm 1000 bp fragment and primer KSF/R (f: 5'-CSATGGAYCCSCARCARCGSV T-3'), (r: 5'-GTSCCSGTS CCRTGSSCYTCSAC-3') which targeted \pm 700 bp fragment, respectively (Schirmer et al., 2005). The mixture of PCR reaction consisted of $50 \mu \mathrm{L}$ PCR mix containing $25 \mu \mathrm{L}$ GoTaq Green ${ }^{\circledR}$ Master Mix 123 (Promega), $5 \mu \mathrm{L}$ of 10 pmol reverse primer, $5 \mu \mathrm{L}$ of $10 \mathrm{pmol}$ forward primer, $11 \mu \mathrm{L}$ nuclease-free water and $4 \mu \mathrm{L}$ DNA template $(100 \mathrm{ng} / \mu \mathrm{L})$. PCR conditions were carried out in three steps including predenaturation at $94^{\circ} \mathrm{C}$ for $5 \mathrm{~min}$, followed by 35 cycles of denaturation at $94^{\circ} \mathrm{C}$ for $1 \mathrm{~min}$, annealing at $58^{\circ} \mathrm{C}$ for $1 \mathrm{~min}$, elongation at $72^{\circ} \mathrm{C}$ for $1 \mathrm{~min}$ and post PCR at $72^{\circ} \mathrm{C}$ for $10 \mathrm{~min}$. The PCR products were sequenced in First Base, Malaysia. The sequences were then compared to the database of National Center for Biotechnology Information (NCBI) using the BlastX program. The phylogenetic tree was constructed by using Molecular Evolutionary Genetics Analysis (MEGA) 7.0 program with the neighborjoining method in 1000x bootstrap replications.

\section{Identification of the Most Potential Bacteria based on $16 S$ rRNA Gene}

16S rRNA gene was amplified using universal primer for bacteria, 63f (5'-CAG GCC TAA CAC ATG CAAGTC-3') and 1387r (5'-GGG CGG WGT GTA CAA GGC-3' (Marchesi et al., 1998) which targeted the conserved region approximately 1300-bp fragment. Fifty $\mu \mathrm{L}$ PCR mix consisted of $25 \mu \mathrm{L}$ GoTaq Green ${ }^{\circledR}$ Master Mix 123 (Promega), $5 \mu \mathrm{L}$ of 10 pmol $1387 \mathrm{r}$ primer, $5 \mu \mathrm{L}$ of 10 pmol $63 \mathrm{f}$ primer, $11 \mu \mathrm{L}$ nuclease-free water and 4 
$\mu \mathrm{L}$ DNA template $(100 \mathrm{ng} / \mu \mathrm{L})$. PCR conditions were carried out in 35 cycles with predenaturation at $94^{\circ} \mathrm{C}$ for $5 \mathrm{~min}$, denaturation at $94^{\circ} \mathrm{C}$ for $30 \mathrm{sec}$, annealing at $55^{\circ} \mathrm{C}$ for $45 \mathrm{sec}$, elongation at $72^{\circ} \mathrm{C}$ for $1 \mathrm{~min} 45 \mathrm{sec}$ and postelongation at $72^{\circ} \mathrm{C}$ for $10 \mathrm{~min}$. The PCR products were sequenced in First Base, Malaysia. The sequences were compared by using the BlastN program in National Center for Biotechnology Information (NCBI) GenBank database. The sequences were deposited to NCBI GenBank (https://www.ncbi.nlm.nih.gov). Construction of phylogenetic tree was constructed using MEGA 7.0 software by neighbor-joining method with $1000 x$ bootstrap replications.

\section{Antagonism Assay for Culture and Supernatant of the Potential Bacterium}

The potential bacterium with the widest spectrum in inhibiting three different Vibrio sp was used for this assay. Twenty four hours of bacterial suspension was counted by a direct-count method using hemocytometer. Nearly $1.5 \mathrm{~mL}$ of that suspension was centrifuged in $10.000 \mathrm{rpm}$ for $5 \mathrm{~min}$. The pellets and supernatants were separated into different tubes. The pellets were diluted with $150 \mu \mathrm{L}$ of supernatants, so that the suspension contains ten times of cell number. Then, $20 \mu \mathrm{L}$ of that concentrated culture was dropped onto the SWC agar medium containing the bacterial target. For the comparison, $20 \mu \mathrm{L}$ of supernatants were also inoculated on that medium and the plates were incubated for $24 \mathrm{~h}$ at $\pm 27^{\circ} \mathrm{C}$.

\section{Antagonism Assay of Bacterial Crude Extract}

Ten $\mathrm{mL}$ of $24 \mathrm{~h}$ bacterial suspension was used as a starter and inoculated into $1 \mathrm{~L}$ of liquid SWC medium. The culture was incubated and shaken at $120 \mathrm{rpm}$ for 3 days at $\pm 27^{\circ} \mathrm{C}$. The bacterial culture was then extracted by adding ethyl acetate solvent $1: 1(\mathrm{v} / \mathrm{v})$ and shaken continously for $20 \mathrm{~min}$. The solvent layer was separated and evaporated using rotary evaporator at $42^{\circ} \mathrm{C}$. The bacterial crude extracts obtained were diluted in DMSO. $20 \mu \mathrm{L}$ of $1000 \mathrm{ppm}$ crude extract was dropped into the steril paper disk and put on SWC medium plate containing the bacterial target. DMSO and $100 \mathrm{ppm}$ of ampicillin were applied as a negative and positive control, respectively. The plates were incubated for $24 \mathrm{~h}$ at $\pm 27^{\circ} \mathrm{C}$. This assay was conducted in triplicates.

\section{Results}

\section{Bacteria Isolated from Sponges}

Isolation of sponge-associated bacteria from 3 different sponges resulted 80 bacterial isolates which were morphologically different. Nine bacterial isolates were obtained from sponge Hyrtios sp., 20 bacteria isolated from Smenospongia sp. and 51 bacteria isolated from Verongula sp.

\section{Sponge-Associated Bacteria with Anti-Vibrio sp Properties}

Of 80 bacterial isolates, 12 isolates $(15 \%)$ were able to inhibit Vibrio's growth indicated by clear zone formation around the bacterial colonies (Table 1). One bacterial isolate, coded as P2.24, could inhibit three Vibrio species, including $V$. harveyi, $V$. parahaemolyticus and $V$. vulnificus. In addition, 10 bacterial isolate specifically only inhibit $V$. harveyi and 1 bacterial isolate coded as P3.310 could inhibit both $V$. harveyi and $V$. parahaemolyticus. Twelve bacterial isolates showed a diverse clear zone diameter, ranging from $0.1 \mathrm{~mm}$ to $5 \mathrm{~mm}$. The best anti-Vibrio activity showed by P2.24 isolate due to its ability to inhibit three Vibrio species with different clear zone diameter. To confirm its anti-Vibrio spp activities, the concentrated culture, supernatants and metabolite extracts of the P2.24 isolate were tested in antagonism assay.

\section{Hemolytic Reaction of the Potential Bacteria}

Twelve bacterial isolates producing anti-Vibrio sp compounds were hemolytic negative. They did not lyse blood cells as indicated by no clear zone formed around the colony after $24 \mathrm{~h}$ of incubation.

\section{The Identity of NRPS-PKS Gene and 16S rRNA of the Selected Bacterial Isolates}

Based on their ability in inhibiting Vibrio's growth in wide spectra, three out of 4 potential bacterial isolates coded as P2.24, P3.310 and D4.13 have been identified to have both NRPS and PKS genes and one bacterial isolate coded as P2.211, did not have both genes. Adenylation (A) domain of NRPS and ketosynthase (KS) domain of PKS gene from these bacteria have been amplified by PCR method resulting \pm 1000 bp and \pm 700 bp DNA fragment, respectively (Fig. 1). Alignment using the BlastX revealed all NRPS and PKS genes were similar with NRPS and PKS genes of Bacillus spp in various strains (Table 2 and 3 ). In addition, amplification of 16S rRNA gene of four bacterial isolates resulted \pm 1300 bp DNA fragment. All these isolates were homolog with Bacillus sp (Table 4).

The genetic relationship for NRPS-PKS gene of the potential isolates was compared with their relative gene in GenBank NCBI database and some references by constructing the phylogenetic tree. The phylogenetic tree of A domain of NRPS gene and KS domain of PKS gene are shown in Fig. 2 and 3, respectively. The evolutionary relationship based on $16 \mathrm{~S}$ rRNA of the potential bacterial isolate with their closest related strains is performed in Fig. 4. 
Aris Tri Wahyudi et al. / American Journal of Biochemistry and Biotechnology 2018, 14 (3): 221.229 DOI: 10.3844/ajbbsp.2018.221.229

Table 1: Growth inhibition of Vibrio sp by sponge-associated bacteria

\begin{tabular}{|c|c|c|c|c|}
\hline \multirow[b]{2}{*}{ Sponge } & \multirow[b]{2}{*}{ Isolate code } & \multicolumn{3}{|c|}{ Growth inhibition of Vibrio species ${ }^{1)}$} \\
\hline & & $V$. harveyi & V. parahaemolyticus & V.vulnificus \\
\hline \multirow[t]{4}{*}{ Hyrtios sp. } & D4.13 & +++ & - & - \\
\hline & D4.15 & + & - & - \\
\hline & D4.19 & + & - & - \\
\hline & D4.110 & + & - & - \\
\hline \multirow[t]{4}{*}{ Verongula sp. } & $\mathrm{P} 2.24$ & + & ++ & + \\
\hline & P2.211 & +++ & - & - \\
\hline & $\mathrm{P} 2.212$ & + & - & - \\
\hline & $\mathrm{P} 2.34$ & + & - & - \\
\hline \multirow[t]{4}{*}{ Smenospongia sp. } & P3.310 & + & ++ & - \\
\hline & P3.414 & + & - & - \\
\hline & P3.415 & + & - & - \\
\hline & P3.514 & ++ & - & - \\
\hline
\end{tabular}

${ }^{1)}$ Clear zone diameter $0 \mathrm{~mm}:-$; 0.1-2.5 mm: + ; $2.5-5 \mathrm{~mm}:++;>5 \mathrm{~mm}:+++$

Table 2: The identity of DNA fragment encoding A domain of NRPS gene from3 bacterial isolates producing anti-Vibrio sp compounds using BlastX

\begin{tabular}{|c|c|c|c|c|c|}
\hline Isolate code & Closest NRPS Relative & Query cover $(\%)$ & Similarity $(\%)$ & E-value & Accession \\
\hline D4.13 & Surfactin NRPS SrfA Bacillus sp. strain CMAA 1185 & 96 & 53 & $8 \mathrm{e}-64$ & WP_046160043.1 \\
\hline P3.310 & Surfactin NRPS SrfA Bacillus sp. strain LM 4-2 & 94 & 56 & $6 e-52$ & WP 046380780.1 \\
\hline P2.24 & Non-ribosomal peptide synthetase Bacillus amiloquifaciens & 85 & 42 & $2 \mathrm{e}-15$ & WP_021493393.1 \\
\hline
\end{tabular}

Table 3: The identity of DNA fragment encoding KS domain of PKS gene from 3 bacterial isolates producing anti-Vibrio sp. compounds using BlastX

\begin{tabular}{lllll}
\hline Isolate code & Closest PKS Relative & Query Cover (\%) & Similarity (\%) & E-value \\
\hline D4.13 & Ketosynthase; Bacillus subtilis & 99 & 100 & $8 \mathrm{e}-159$ \\
P3.310 & Ketosynthase; Bacillus subtilis, & 99 & 99 & SAJ35050.1 \\
P2.24 & Ketosynthase; Bacillus sp. strain IX-119, & 93 & 61 & SAJ35050.1 \\
\hline
\end{tabular}

Table 4: The identity of 4 bacterial isolates producing anti-Vibrio sp compounds based on 16S rRNA gene using BlastN

\begin{tabular}{|c|c|c|c|c|c|}
\hline Isolate code (Accession No.) & Closest relative & Query Cover (\%) & Similarity $(\%)$ & E-value & Accession \\
\hline D4.13 (MH588269.1) & Bacillus subtilis strain PHYDG1 & 99 & 98 & 0.0 & KY785660.1 \\
\hline P3.310 (MH588271.1) & Bacillus subtilis strain R242 & 100 & 98 & 0.0 & KY515422.1 \\
\hline P2.24 (MH588270.1) & Bacillus subtilis strain Y10 & 100 & 97 & 0.0 & KC708563.1 \\
\hline P2.211 (MH588272.1) & Bacillus flexus strain SML I301 & 100 & 99 & 0.0 & MG937596.1 \\
\hline
\end{tabular}

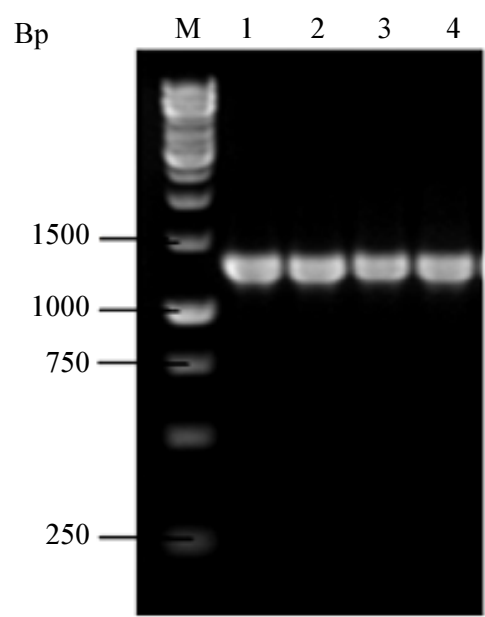

(A)

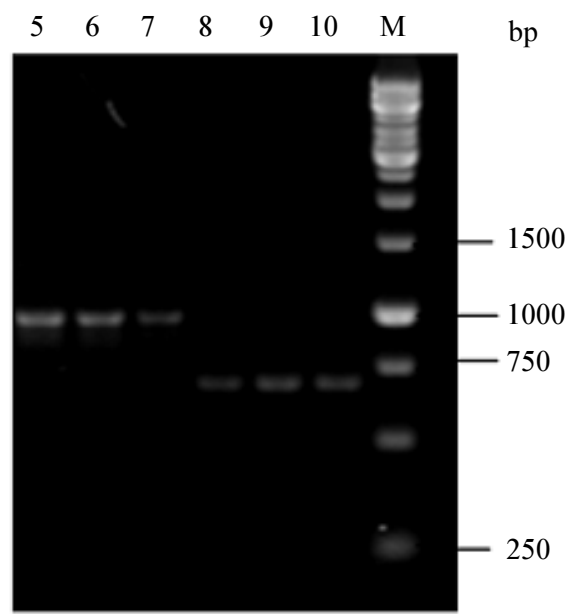

(B)

Fig. 1: Visualization by 1\% agarose of (A) 16S rRNA gene and (B) NRPS-PKS gene. 16S rRNA gene ( 1300 bp) (1) D4.13, (2) P3.310, (3) P2.24, (4) P2.211; A domain of NRPS gene ( 1000 bp): (5) D4.13, (6) P3.310, (7) P2.24 and KS domain of PKS gene ( 700 bp): (8) D4.13, (9) P3.310, (10) P2.24 and (M) Marker 1 kb ladder 


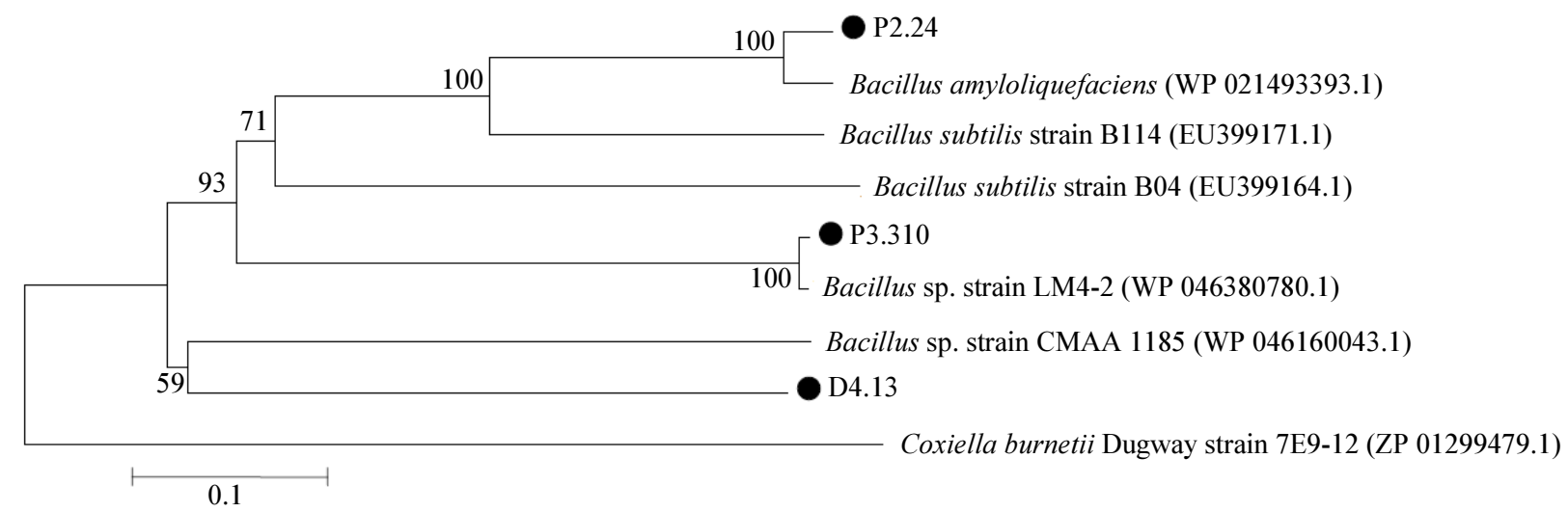

Fig. 2: The phylogenetic tree of A domain of NRPS gene of the bacterial isolates compared with their closest relative sequences in the Genbank database and some references sequences

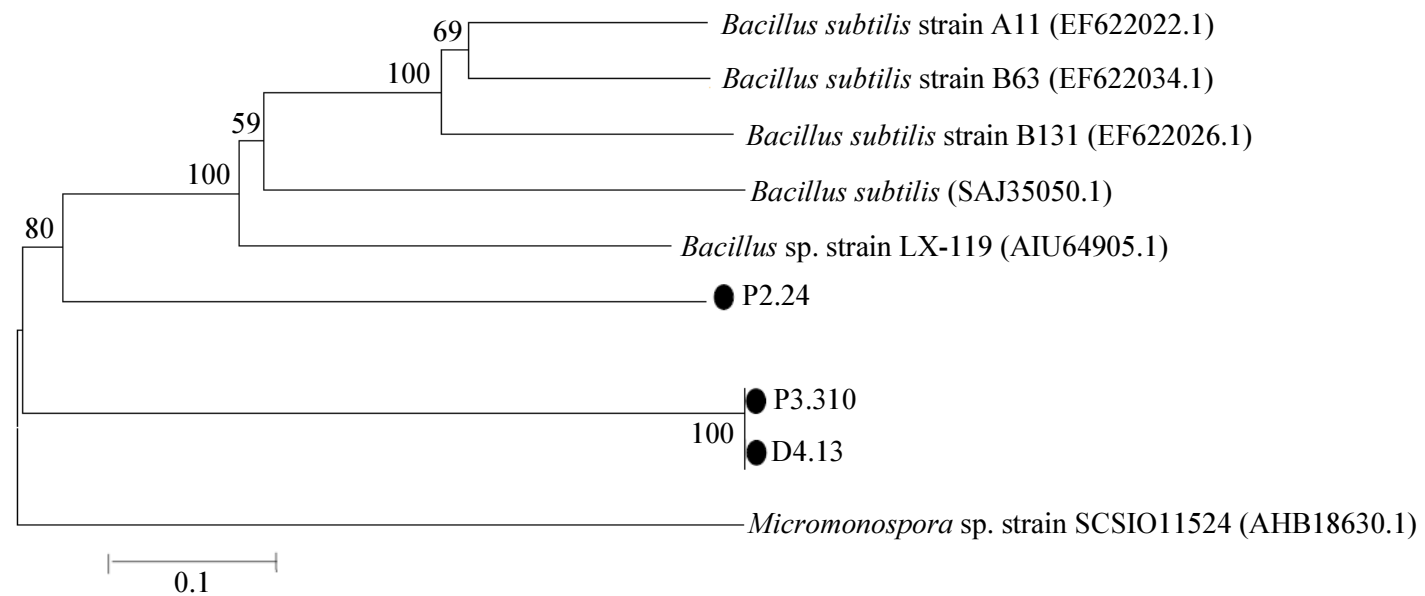

Fig. 3: The phylogenetic tree of KS domain of PKS gene of the bacterial isolates compared with their related species

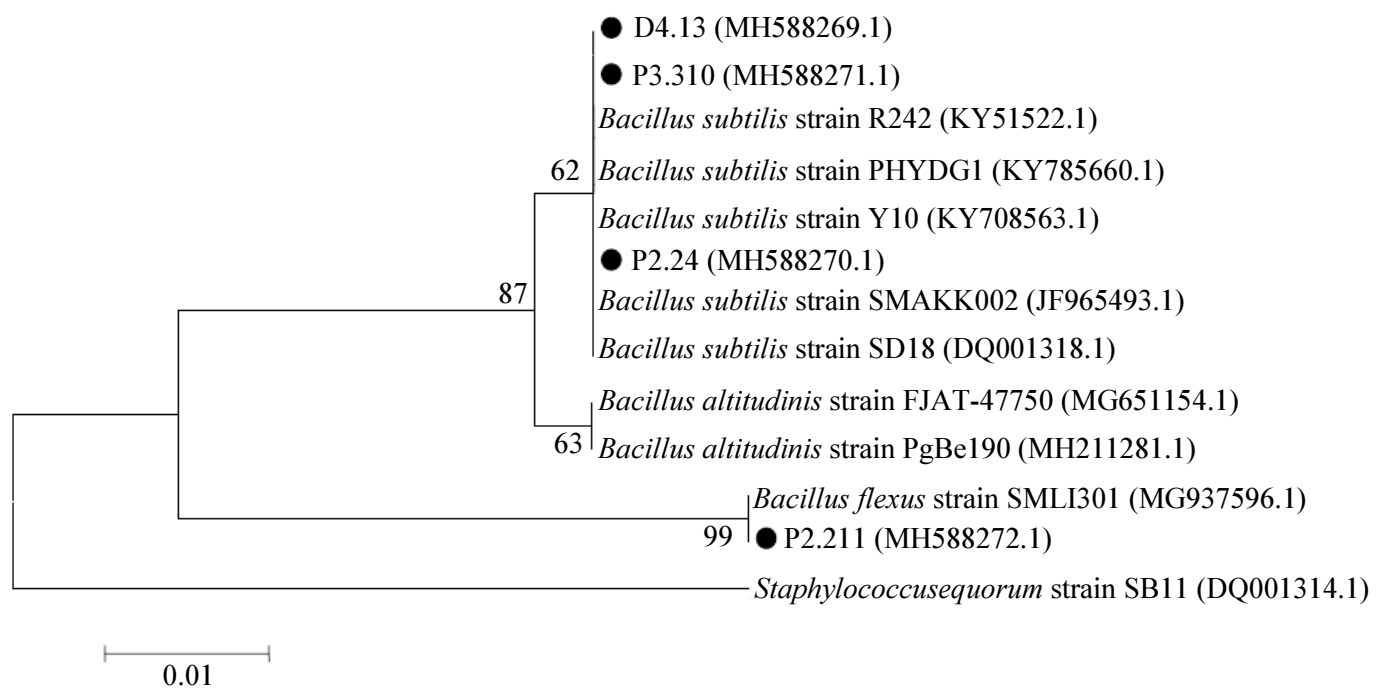

Fig. 4: The phylogenetic tree of the bacterial isolates based on 16S rRNA gene compared with their closest related species 


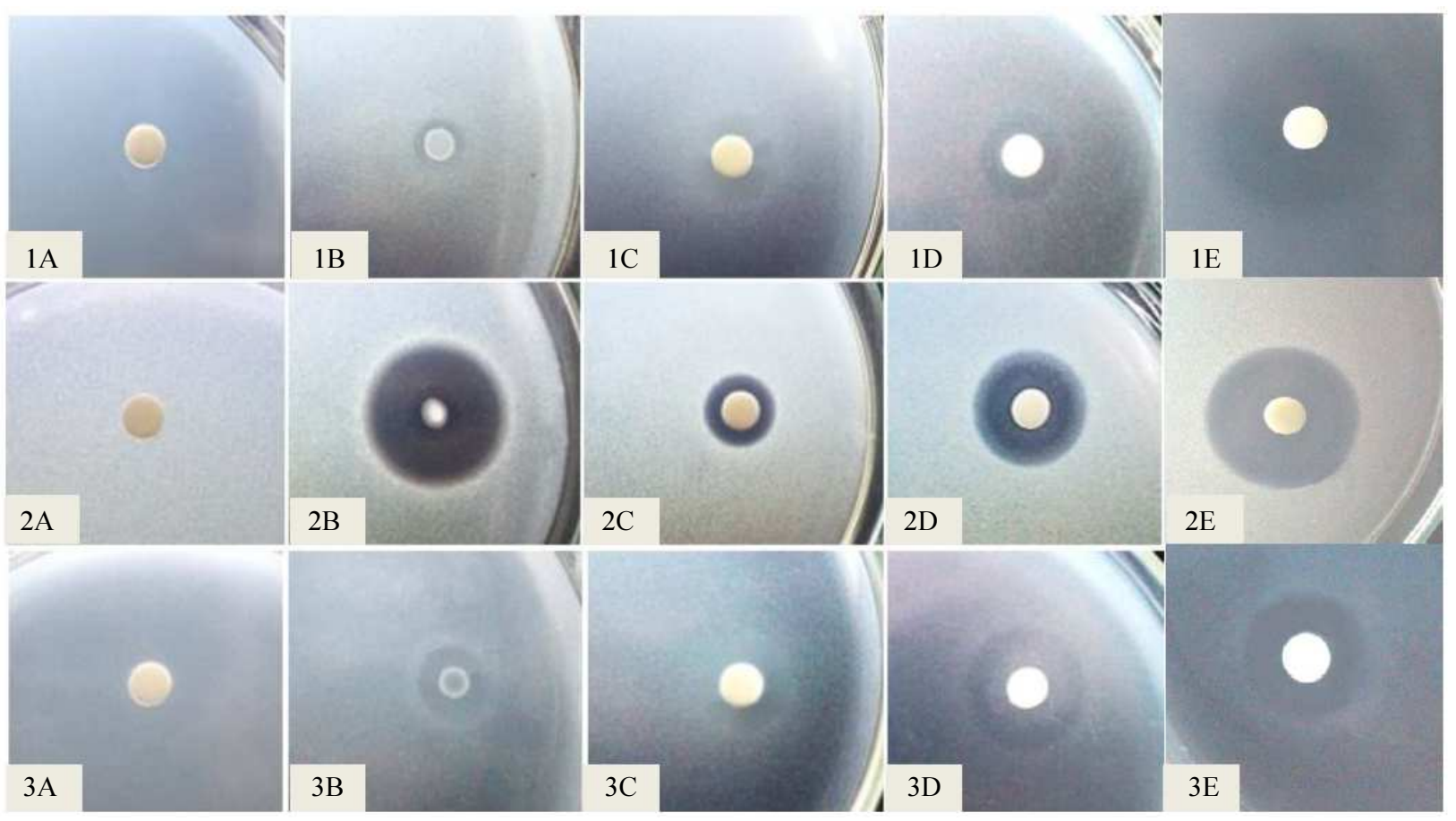

Fig. 5: Anti-Vibrio sp activities of the bacterial isolate P2.24 confirmed by its concentrated culture, supernatants and metabolite extracts, against three Vibrio species: $V$. harveyi (1), V. parahaemolyticus (2), V. vulnificus (3). Negative control (DMSO) (A), concentrated culture (B), supernatant (C), $1000 \mathrm{ppm}$ of crude extracts of bacterial metabolites (D) and $100 \mathrm{ppm}$ of ampicillin as positive control (E)

\section{Antibacterial Activity of Culture, Supernatant and Extract of P2.24}

Bacterial culture used in this assay contains approximately $7.8 \times 107 \quad$ cell $/ \mathrm{mL}$ medium. Culture, supernatant, as well as the extract of the isolate P2.24 consistently exhibited anti-Vibrio sp activities as indicated by clear zone formation around paper disk (Fig. 5). The strongest inhibitory effect was shown by the concentrated culture of the isolate P2.24 against $V$. parahaemolyticus. The clear zone was also exhibited by ampicillin as positive control. There was no clear zone obtained from DMSO as negative control.

\section{Discussion}

In this study, twelve out of 80 bacterial isolates or about $15 \%$ bacteria isolated from three sponges exhibited their ability to inhibit Vibrio species growth. The ability of these bacteria to produce anti-Vibrio compunds indicated by clear zone formation around bacterial colonies. The bioactive compounds produced by these bacteria may inhibit the growth of Vibrio bacteria. The synthesis of bioactive compounds is an important defense mechanism as a protection from environmental stress and pathogen colonization, both for the bacteria itself and for its host (Lee et al., 2001). Twelve bacterial isolates showed various spectra in inhibiting Vibrio spp.
The different anti-Vibrio spectra indicating the diversity of antimicrobial compounds produced by these spongeassociated bacteria. Different compounds may have different mechanisms in inhibiting Vibrio colonization. The resistance capability of each Vibrio species also might influence the effectivity of bioactive compounds work. Twelve bacterial strains also showed a nonhemolytic reaction on blood agar suggesting that these bacteria were not the pathogen.

An indication of capability in producing anti-Vibrio $\mathrm{sp}$ compounds of the potential bacterial isolate has been confirmed by molecular evidence. The Adenylation (A) domain of the NRPS gene and Ketosynthase (KS) domain of the PKS gene are the most conserved domain compared to other domains (Schirmer et al., 2005). Both A domain and KS have been identified in three potential bacterial genome. The enzyme polyketide synthase and non-ribosomal peptide synthetase are multidomain enzyme that responsible for biosynthesis of bioactive compounds in many microorganisms, including bacteria (Su et al., 2014), actinomycetes (Ziemert et al., 2014; $\mathrm{Xi}$ et al., 2012) and fungi (Boettger and Hertweek, 2013). Those three bacterial isolates coded as P2.24, P3.310 and D4.13 with NRPS and PKS gene allowed the possibility to synthesize bioactive compounds by hybrid NRPS-PKS pathway. According to Zhu et al. (2009), Hybrid NRPS-PKS gene may occur with a combination 
of domains from both genes in an open reading frame. The hybrid NRPS-PKS has potential to synthesis novel bioactive compounds with hybrid structure. Leinamycin is an antitumor compound derived from Streptomyces atroolivaceus which synthesis of that compound by hybrid NRPS-PKS gene (Tang et al., 2004).

The KS sequence alignment in amino acid level showed that all KS sequences were similar with type I PKS gene of Bacillus spp in a various percentage of similarity, while A sequences of three bacterial isolates were similar to NRPS gene of Bacillus spp. The low similarity value of the genes may indicate the unavailability of data in the Genbank NCBI database for the same genus or bacterial species. The results also allow for the novelty of the genes involved in synthesis of new bioactive compounds (Zhang et al., 2009a).

Based on 16S rRNA gene, bacterial isolate P2.24, the widest anti-vibrio spectra producer, was highly homolog with Bacillus subtilis strain Y10 with 97\% similarity, while three other strains were also identified as Bacillus sp with high similarity. Marine Bacillus is one of the biggest bioactive compounds producers group. Some previous studies reported that some Bacillus strains isolated from South China Sea sponge exhibited an excellent antimicrobial activity against Staphylococcus aureus, Aspergillus niger, Candida albican, Pseudomonas fluorescens, B. subtilis and E.coli (Zhang et al., 2009b). Supporting the study, Manikandan et al. (2014) also reported Bacillus subtilis strain SMAKK002 isolated from marine sponge exhibited the strong antimicrobial activity against some multidrug resistance human pathogens.

The bacterial isolate P2.24 was the only one bacterium that had the widest spectra of anti-Vibrio's bioactive compounds against all three Vibrio species, including Vibrio harveyi, $V$. parahaemolyticus, $V$. vulnificus. The consistent anti-Vibrio activity was also performed by concentrated culture, supernatants and metabolites extracts of that bacterium. The inhibitory zone formation around the bacterial colony indicates the diffusion of bioactive compounds synthesized by the bacterium on the growth medium so that targeted bacteria growth around diffusion area was inhibited. The bioactive compounds produced by $\mathrm{P} 2.24$ isolate was an extracellular compound, as it indicated by the inhibition of Vibrio's growth when supernatant was tested through antagonism assay.

In addition, the anti-Vibrio activity of P2.24 isolate was also confirmed by its metabolites crude extract. However, it still crude extract. It would be important to purify, separate and identify the crude extract compounds. In some previous studies, anti-Vibrio activity of crude extracts derived from sponge-associated bacteria has also been reported, but the activity of these extracts only inhibited one Vibrio species. As examples, bioactive compounds from Flavobacterium sp isolated from Acropora muricata sponge only inhibited the growth of $V$. harfeyi (Ginting et al., 2010). Crude extracts from bacteria isolated from Acanthostrongylophora $\mathrm{sp}$ only inhibited $V$. cholerae as reported by Legina (2016). The anti-Vibrio activities of the P2.24 have the potency to be further developed to control vibriosis disease in aquaculture since their broader antiVibrio spectrum properties in inhibiting more than one Vibrio species. On the other hand, to elaborate this result, it is also necessary to purify the bioactive compound so that the kind of compound that plays a role in the inhibition of Vibrio sp can be known.

\section{Conclusion}

Of 80 isolates isolated from marine sponges Hyrtios sp, Verongula sp., and Smenospongia sp, 12 isolates $(15 \%)$ had anti-Vibrio activities in different spectra. Of 4 bacterial isolates with the best antivibrio activity, three isolates have been identified to have PKS and NRPS genes. Based on 16S rRNA gene, those 4 isolates were highly homolog to Bacillus genera. One bacterial isolate coded as P2.24 was the only bacterium that had the widest spectra of antiVibrio's bioactive compounds as tested by antagonism assay using culture, supernatant and crude extract of the bacterium. This P2.24 is important to be further exploited for controlling vibriosis biologically and essential for the elucidation of bioactive compounds synthesized by this bacterium.

\section{Acknowledgment}

The authors appreciate to the Ministry of Research, Technology and Higher Education that have promoted this project through "Penelitian Berbasis Kompetensi (Competence-Based Research) 2018" to ATW. The nucleotide sequences of $16 \mathrm{~S}$ rRNA genes reported are available in the NCBI GenBank database under Accession Numbers MH588269.1, MH588270.1, MH588271.1 and MH588272.1.

\section{Funding Information}

Part of this work was funded by "Penelitian Berbasis Kompetensi (Competence-Based Research) 2018" from the Ministry of Research, Technology and Higher Education of Indonesia.

\section{Author's Contributions}

Aris Tri Wahyudi: Has guided the project, determined the research framework, data analysis and involved in paper writing. 
Jepri Agung Priyanto: Has contributed to the experimental works, data analysis and paper writing.

Wenang Maharsiwi: Has contributed in the experimental works and data analysis.

Rika Indri Astuti: Has contributed to the interpretation of data and paper writing.

\section{Ethics}

This article is original from the authors works. The corresponding author ensures that all of the other authors have read and recognized the manuscript.

\section{References}

Abubakar, H., A.T. Wahyudi and M. Yuhana, 2011. Skrining bakteri yang berasosiasi dengan spons Jaspis sp. sebagai penghasil senyawa antimikroba. ILMU Kelautan, 16: 35-40.

DOI: $10.14710 /$ ik.ijms.16.1.35-40

Aguirre-Guzman, G., E.A. Lopez-Acevedo and M.D.L. Vazquez-Sauceda, 2013. Vibrio harveyi effect under survival of Litopenaeus vannamei larvae. Scientia Agropecuaria, 4: 121-127.

DOI: $10.17268 /$ sci.agropecu.2013.02.05

Boettger, D. and C. Hertweck, 2013. Molecular diversity sculpted by fungal PKS-NRPS hybrids. Chembiochem, 14: 28-42. DOI: $10.1002 /$ cbic. 201200624

Brinkmann, C.M, A. Marker and D.I. Kurtboke, 2017. An overview on marine sponge-symbiotic bacteria as unexhausted sources for natural product discovery. Diversity, 9: 40-40. DOI: $10.3390 / \mathrm{d} 9040040$

Chatterjee, S. and S. Haldar, 2012. Vibrio related diseases in aquaculture and development of rapid and accurate identification methods. J. Marine Sci. Res. Dev., S1: 002-002. DOI: $10.4172 / 2155-9910 . S 1-002$

Ginting, E.L., V. Warouw and R.W. Suleman, 2010. Aktivitas antibakteri dari ekstrak kasar bakteri yang berasosiasi dengan sponge Acanthostrongylophora sp. J. Perikanan dan Kelautan Tropis, 6: 160-163.

Hassan, I. and H.A.H. Ibrahim, 2016. Production, characterization and valuable applications of exopolysaccharides from marine Bacillus subtilis SH1. Polish J. Microbiol., 66: 449-461.

Lee, Y.K., J.H. Lee and H.K. Lee, 2001. Microbiol symbiosis in marine sponge. J. Microbiol., 39: 254-264.

Legina, R.S., 2016. Penggunaa ekstrak bakteri Flavobacterium sp. dari karang Acropora muricata sebagai antibakteri terhadap Vibrio harveyi. Hasanuddin University, Makassar (ID).
Manikandan, S., S. Ganesapandan, N. Sangeetha and A.K. Kumaraguru, 2014. Antimicrobial activity of marine sponge associated some marine bacterial metabolites against multi drug resistance human pathogens. Res. J. Microbiol., 9: 25-33. DOI: $10.3923 / \mathrm{jm} .2014 .25 .33$

Marchesi, J.R., T. Sato, A.J. Weightman, T.A. Martin and J.C. Fry et al., 1998. Design and evaluation of useful bacterium-specific PCR primers that amplify genes coding for bacterial 16S rRNA. Applied Environ. Microbiol., 64: 795-799. PMID: 9464425

Ozkaya, F.H., S. Engin, T.T. Tanrikul and M. Altunok, 2014. Screening of sponge associated fungi for antimicrobial activity against fish pathogens. Akademik Platform.

Rini, A.F., M. Yuhana and A.T. Wahyudi, 2017. Potency of sponge-associated bacteria producing bioactive compounds as biological control of vibriosis on shrimp. J. Akuakultur Indonesia, 16: 41-50. DOI: 10.19027/jai.16.1.41-50

Schirmer, A., R. Gadkari, C.D. Reeves, F. Ibrahim and E.F. De Long et al., 2005. Metagenomic analysis reveals diverse polyketide synthase gene cluster in microorganisms associated with the marine sponge Discodermia dissoluta. Applied Environ. Microbiol., 71: 4840-4849. DOI: 10.1128/AEM.71.8.4840-4849.2005

Selvin, J. and A.P. Lipton, 2004. Dendrilla nigra, a marine sponge, as potential source of antibacterial substances for managing shrimp diseases. Aquaculture, 236: 277-283. DOI: $10.1016 /$ j.aquaculture.2004.01.021

Su, P., D.X. Wang, S.X. Ding and J. Zhao, 2014. Isolation and diversity of natural product biosynthetic genes of cultivable bacteria associated with marine sponge Mycale sp. from the coast of Fujian, China. Canad. J. Microbiol., 60: 217-225. DOI: 10.1139/cjm-2013-0785

Tang, G.L., Y.Q. Cheng and B. Shen, 2004. Leinamycin biosynthesis revealing unprecedented architectural complexity for a hybrid polyketide synthase and nonribosomal peptide synthetase. Chem. Biol., 11: 33-45. DOI: 10.1016/j.chembiol.2003.12.014

Taylor, M.W, R. Radax, D. Steger and M. Wagner, 2007. Sponge-associated microorganisms: Evolution, ecology and biotechnological potential. Microbiol. Mol. Biol. Rev., 71: 295-347.

DOI: 10.1128/MMBR.00040-06

Xi, L, J. Ruan and Y. Huang, 2012. Diversity and biosynthetic potential of culturable actinomycetes associated with marine sponges in the China Seas. Int. J. Mol. Sci., 13: 5917-5932.

DOI: $10.3390 /$ ijms 13055917 
Yoghiapiscessa, D., I. Batubara and A.T. Wahyudi, 2016. Antimicrobial and antioxidant activities of bacterial extracts from marine bacteria associated with sponge Stylotella sp. Am. J. Biochem. Biotechnol., 12: 36-46.

DOI: 10.3844 /ajbbsp.2016.36.46

Zhang, W., F. Zhang, Z. Li, X. Miao and Q. Meng et al., 2009a. Investigation of bacteria with polyketide synthase genes and antimicrobial activity isolated from South China Sea sponges. J. Appljied Microbiol., 107: 567-575.

DOI: 10.1111/j.1365-2672.2009.04241.x

Zhang, W., Z. Li, X. Miao and F. Zhang, 2009b. The screening of antimicrobial bacteria with diverse novel Nonribosomal Peptide Synthetase (NRPS) genes from South China Sea sponges. Mar. Biotechnol., 11: 346-355. DOI: 10.1007/s10126-008-9148-z
Zhu, P., Y. Zheng, X. Yan and J. Shao, 2009. Molecular phylogeny and modular structure of hybrid NRPS/PKS gene fragment of Pseudoteromonas sp. NJ6 3-2 isolated from marine sponge Hymeniacidon perleve. J. Microbiol. Biotechnol., 19: 229-237.

Ziemert, N., A. Lechner, M. Wietz, N. MillánAguiñaga and K.L. Chavarria et al., 2014. Diversity and evolution of secondary metabolism in the marine actinomycete genus Salinispora. PNAS, 111: E1130-E1139.

DOI: $10.1073 /$ pnas. 1324161111 